\title{
Antidepressant Effect and Recognition Memory Improvement of Two Novel Plant Extract Combinations - Antistress I and Anti- stress II on Rats Subjected to a Model of Mild Chronic Stress
}

\author{
Ilin K. Kandilarov ${ }^{1}$, Hristina I. Zlatanova ${ }^{1}$, Maria T. Georgieva-Kotetarova' , Ivanka I. Kostadi- \\ nova ${ }^{1}$, Mariana N. Katsarova ${ }^{2}$, Stela Z. Dimitrova ${ }^{2}$, Ludmil K. Lukanov ${ }^{2}$, Ferit Sadakov ${ }^{3}$ \\ ${ }^{1}$ Department of Pharmacology and Clinical Pharmacology, Faculty of Medicine, Medical University of Plovdiv, Plovdiv, Bulgaria \\ 2 Department of Chemistry and Biochemistry, Faculty of Pharmacy, Medical University of Plovdiv, Plovdiv, Bulgaria \\ ${ }^{3}$ Avicena herb-Ltd., Plovdiv, Bulgaria
}

\begin{abstract}
Correspondence:
Ilin K. Kandilarov, Department of Pharmacology and Clinical Pharmacology, Faculty of Medicine, Medical University of Plovdiv, 15A Vassil Aprilov Blvd., 4002 Plovdiv, Bulgaria

E-mail: ilin.kandilarov@gmail.com Tel: +359892731591
\end{abstract}

Received: 13 March 2017

Accepted: 24 June 2017

Published Online: 31 Aug 2017

Published: 30 March 2018

Key words: chronic stress, forced swim test, novel object recognition test, plant extract combinations, serratula coronata

Citation: Kandilarov IK, Zlatanova $\mathrm{HI}$, Georgieva-Kotetarova MT, Kostadinova II, Katsarova MN, Dimitrova SZ, Lukanov LK, Sadakov F. Antidepressant effect and recognition memory improvement of two novel plant extract combinations - antistress I and antistress II on rats subjected to a model of mild chronic stress. Folia Med (Plovdiv) 2018;60(1):110-6.

doi: 10.1515/folmed-2017-0073
Background: Chronic stress is one of the main factors which lead to depression - a psychiatric disorder affecting millions of people and predicted to be the second ranked cause of premature death in 2020. Depression is often associated with cognitive disturbances and memory deficit. Plant based therapy could be effective in the treatment of mild to moderate depression due to its low level of adverse reaction, its good tolerability and compliance.

Materials and methods: 72 male Wistar rats, divided in 9 groups were given orally for 8 weeks two combinations of dry plant extracts - Antistress I and Antistress II and five individual dry extracts obtained from Serratula coronata, Hypericum perforatum, Valeriana officinalis, Crataegus monogyna and Melissa officinalis. The animals were exposed to a chronic unpredictable mild stress for 8 weeks. The depression-like symptoms were evaluated with Forced swim test while the assessment of the memory deficit was performed with Novel object recognition test.

Results: Antistress II demonstrates antidepressant effect while Antistress I doesn't improve the depressive-like symptoms. The individual extracts of Hypericum perforatum and Valeriana officinalis also possess antidepressant properties. Antistress II improves the cognition as well as the individual extracts of Hypericum perforatum, Valeriana officinalis and especially Serratula coronata. Dry extract from Serratula tend to have the best effect regarding the recognition memory. The effect of Antistress I on memory deficit is negligible.

Conclusions: Antistress II possesses antidepressant effect and improves the recognition memory while Antistress I doesn't demonstrate any of the above-described effects.

\section{BACKGROUND}

Depression is considered to be one of the major psychiatric disorders, affecting nearly 350 million people worldwide. It is one of the most common and devastating diseases with a tendency to become the second ranked cause of premature death and disability by the year 2020. ${ }^{1}$ Stress is considered to be one of main factors, leading to depression in both humans and rodents. ${ }^{2,3}$ The exposure to a variety of unpredictable mild stressors could engender depressive-like symptoms in rats thus a chronic stress paradigm could be used as a reliable model for inducing depression in rodents. ${ }^{4}$ In rats the disease is manifested by decreased aggressive, sexual and investigative behavior. A cognitive disturbance and an impaired ability to recognize new objects could also be observed as symptoms of depression. Thus behavior changes and recognition memory could be used as indicators for depression. ${ }^{5}$ The use of efficient antidepressants which 
possess minimal adverse effects plays a key role in the therapy of depression. ${ }^{6}$ Plant-based therapy has an important role in the primary health care of $80 \%$ of the world's population and is characterized by less adverse reactions, better compliance of patients and good efficiency in the prevention and treatment of various diseases including depression. Products derived from natural sources are unique in their chemical formulas and could be combined in such a way which may improve their efficiency or demonstrate entirely new pharmacological effects. ${ }^{7}$

\section{AIM}

The aim of the present experimental work was to evaluate the antidepressant properties and the effect on recognition memory of Antistress I and Antistress II - two combinations of plant extracts, containing in different proportions individual plant extracts obtained from Serratula coronata, Hypericum perforatum, Valeriana officinalis, Crataegus monogyna and Melissa officinalis.

\section{MATERIALS AND METHODS}

Two combinations of plant extracts - "Antistress I" and "Antistress II" were evaluated in the present experiment. Each of them contains in different proportions individual extracts obtained from five plants - Serratula coronata, Hypericum perforatum, Valeriana officinalis, Crataegus monogyna and Melissa officinalis. The individual extracts were also assessed in this experiment in order to study their part regarding the effect of the combinations.
"Antistress I" contains dry extracts from Valeriana officinalis, Melissa officinalis, Crataegus monogyna and Serratula coronata in ratio of 4:3:3:1. "Antistress II" contains Valeriana officinalis, Hypericum perforatum and Serratula corronata in a ratio of $4.5: 4.5: 1$.

The chemical composition of the dry extracts was identified by developed and validated HPLC methods for determination of 20-hydroxyecdysone, quercetin, hypericin, valerenic acid, bornyl acetate, rutin, hyperoside, rosmarinic and caffeic acid. ${ }^{8}$

The experimental part of the present study evaluated the antidepressant effect and the influence on recognition memory of the two combinations and the five individual extracts. 72 male Wistar rats weighting 150-180 g were divided in 9 groups with 8 animals in each group. Table 1 shows the design of the experiment used for the evaluation of the antidepressant effects and the influence on recognition memory in a model of chronic stress of the two combinations - Antistress I and Antistress II and the individual extracts included in them.

For 8 weeks, the animals were treated daily by using oral gavage at a dose of $500 \mathrm{mg} / \mathrm{kg}$ body weight with the two combinations and the five individual plant extracts. All rats, except those from group $\mathrm{C}_{0}$, were exposed to a model of chronic mild stress which consisted of the following stressors: cage tilt $45^{\circ}$ for 24 hours, damp bedding - $200 \mathrm{ml}$ water in $100 \mathrm{~g}$ sawdust for 24 hours, flashing light (60 flashes/minute) for 3 hours, predator sounds (recording of an adult cat) for 15 minutes, food

Table 1. Design of the experiment used for evaluation of the antidepressant effect and the influence on recognition memory in a model of chronic stress of the two combinations - Antistress I and Antistress II and the individual extracts included in them

\begin{tabular}{cclc}
\hline Group & Label & \multicolumn{1}{c}{ Description } & Model of chronic stress \\
\hline 1 & C & Distilled water per os $10 \mathrm{ml} / \mathrm{kg} \mathrm{b.w.}$ & Yes \\
2 & $\mathrm{C}_{0}$ & Distilled water per os $10 \mathrm{ml} / \mathrm{kg} \mathrm{b.w}$ & No \\
3 & AS1 & Antistress I per os $500 \mathrm{mg} / \mathrm{kg} \mathrm{b} . \mathrm{w}$ & Yes \\
4 & AS2 & Antistress II per os $500 \mathrm{mg} / \mathrm{kg} \mathrm{b.} \mathrm{w}$ & Yes \\
5 & SER & Serratula coronata per os $500 \mathrm{mg} / \mathrm{kg} \mathrm{b} . \mathrm{w}$ & Yes \\
6 & HYP & Hypericum perforatum per os $500 \mathrm{mg} / \mathrm{kg} \mathrm{b} . \mathrm{w}$ & Yes \\
7 & VAL & Valeriana officinalis per os $500 \mathrm{mg} / \mathrm{kg} \mathrm{b} . \mathrm{w}$ & Yes \\
8 & CRA & Crataegus monogyna per os $500 \mathrm{mg} / \mathrm{kg} \mathrm{b} . \mathrm{w}$ & Yes \\
9 & MEL & Melissa officinalis per os $500 \mathrm{mg} / \mathrm{kg} \mathrm{b.} \mathrm{w}$ & Yes \\
\hline
\end{tabular}


deprivation for 24 hours, followed by restricted access of food, water deprivation for 24 hours, followed by empty water bottle exposure for 1 hour. The animals were exposed to one stressor at a time. Each stressor was applied randomly in order to avoid adaptation. After 8 weeks, the rats from all groups were tested for depression and recognition memory.

The Forced swim test is used to evaluate depression in rodents. It consists of two sessions - pretest and test. The pretest is done 24 hours prior to the test. Each animal is placed in a cylindrical tube $20 \mathrm{~cm}$ wide $35 \mathrm{~cm}$ high, filled with $18 \mathrm{~cm}$ water $\left(\mathrm{t}^{\circ}=25^{\circ}\right)$ for $15 \mathrm{~min}$ and then removed and taken back to its cage. The test session is conducted 24 hours later. Each rat is placed in a tube for 5 min and the time of immobility $\left(\mathrm{T}_{0}\right)$ is recorded. The animal is considered immobile when it is not struggling to escape and it is floating, doing only the necessary movements to keep its head above the water. Criterion for antidepressant effect is a significant decrease of $\mathrm{T}_{0} \cdot{ }^{9}$

The recognition memory was assessed by the Novel object recognition test. It has two phases. In the first one which lasts $10 \mathrm{~min}$, the rat is placed in an open field with two identical objects, placed at the opposite corners of the arena. The animal is allowed to explore the objects and then it is removed and taken back to its cage. In the second phase, after a retention time of 1 hour, the rat is returned to the open field and one of the identical objects is replaced with a new - different object. This phase lasts $3 \mathrm{~min}$. The recognition memory was measured by discrimination index (DI). DI is equal to the ratio of time spent studying the new object to the total time spent studying both objects in the test session. Significant increase of DI serves as a criterion for recognition memory. ${ }^{10}$

The use of animals was authorized by the national food safety agency and approved by the university ethical commission. This experiment is part of an interdisciplinary university project.

\section{Statistics}

Statistical assessment of the results was made with IBM SPSS 17.0. Normality of distribution was determined by using Shapiro-Wilk test. Arithmetic mean and SEM were identified for each indicator. Comparison of the results between groups was done by using the Independent Sample t test. P value $<0.05$ was considered statistically significant.

\section{RESULTS}

Table 2 compares the immobility time $-\mathrm{T}_{0}(\mathrm{~s})$, in the Forced swim test after the chronic administration for 8 weeks of Antistress I, Antistress II and the individual extracts, contained in them on male Wistar rats.

The Immobility time decreases significantly for group $\mathrm{C}_{0}$, compared to group $\mathrm{C}$. This proves the validity of the used model of chronic stress in the experiment and the validity of the Forced swim test for measuring the depressive behavior of rats. The rate of $\mathrm{T}_{0}$ diminishes for group AS2 compared to $\mathrm{C}$ and the decrease is statistically significant. For the individual extracts, the reduction of the indicator for depression is significant in groups HYP and VAL compared to C. For all other groups the indicator decreases insignificantly compared to C, except for group AS1 where an insignificant increase could be observed. Table 3 compares the discrimination index (DI), in the Novel object recognition test after chronic administration for 8 weeks of Antistress I, Antistress II and the individual extracts, contained in them on male Wistar rats.

The discrimination index increased for all groups compared to group $\mathrm{C}$. The difference between groups $\mathrm{C}_{0}$ and $\mathrm{C}$ was significant. Regarding the combinations, the increase of DI was statistically significant only for group AS2 compared to C. As for the individual extracts a statistical significant increase of this indicator could be observed in groups SER, HYP and VAL after they are compared to group $\mathrm{C}$.

\section{DISCUSSION}

We haven't found any information in the accessible bibliographical data regarding the exact plant extracts combinations which correspond to the doses, the content and the ratio of the combinations used in our study. In our experiment the time of immobility is reduced in the control group without stress compared with the stressed control, therefore proving the validity of the used chronic stress model and the forced swim test. The group treated with Antistress II at a dose of $500 \mathrm{mg} / \mathrm{kg}$ b.w. reduces significantly the time of immobility. Antistress II contains Hypericum perforatum which is known to exert antidepressant action by inhibiting the reuptake of serotonin, noradrenaline, dopamine and glutamate. Previous studies also have reported a decrease of the immobility time in the Forced 
Table 2. Immobility time $-\mathrm{T}_{0}(\mathrm{~s})$ in the Forced swim test after the chronic administration for 8 weeks of Antistress I, Antistress II and the individual extracts, contained in them on male Wistar rats

\begin{tabular}{ccccc}
\hline Groups & Number & Mean \pm SEM & T & p \\
\hline C & 8 & $225.5 \pm 15.9$ & 2.37 & $0.039^{*}$ \\
C $_{0}$ & 8 & $166.3 \pm 19.2$ & & \\
C & 8 & $225.5 \pm 15.9$ & -0.1 & 0.919 \\
AS1 & 6 & $227.5 \pm 10.4$ & & \\
C & 8 & $225.5 \pm 15.9$ & 2.87 & $0.015^{*}$ \\
AS2 & 7 & $143.4 \pm 22.6$ & & \\
C & 8 & $225.5 \pm 15.9$ & 0.39 & 0.704 \\
SER & 7 & $217.0 \pm 14.7$ & & \\
C & 8 & $225.5 \pm 15.9$ & 2.48 & $0.032^{*}$ \\
HYP & 8 & $163.3 \pm 19.3$ & & \\
C & 8 & $225.5 \pm 15.9$ & 2.23 & $0.046^{*}$ \\
VAL & 8 & $182.5 \pm 11.7$ & & \\
C & 8 & $225.5 \pm 15.9$ & 1.11 & 0.294 \\
CRA & 6 & $192.2 \pm 25.5$ & & \\
C & 8 & $225.5 \pm 15.9$ & 0.98 & 0.348 \\
MEL & 6 & $199.0 \pm 21.7$ & \\
\hline
\end{tabular}

$* \mathrm{P}<0.05$

Table 3. Discrimination index -DI, in the Novel object recognition test after the chronic administration for 8 weeks of Antistress I, Antistress II and the individual extracts, contained in them on male Wistar rats

\begin{tabular}{ccccc}
\hline Groups & Number & Mean \pm SEM & T & p \\
\hline C & 8 & $0.28 \pm 0.03$ & 2.53 & $0.030^{*}$ \\
$\mathrm{C}_{0}$ & 8 & $0.48 \pm 0.07$ & & \\
C & 8 & $0.28 \pm 0.03$ & 1.00 & 0.340 \\
AS1 & 6 & $0.34 \pm 0.05$ & & \\
C & 8 & $0.28 \pm 0.03$ & 2.57 & $0.028^{*}$ \\
AS2 & 7 & $0.44 \pm 0.05$ & & \\
C & 8 & $0.28 \pm 0.03$ & 3.60 & $0.005^{\#}$ \\
SER & 8 & $0.55 \pm 0.07$ & & \\
C & 8 & $0.28 \pm 0.03$ & 2.93 & $0.015^{*}$ \\
HYP & 8 & $0.47 \pm 0.06$ & & \\
C & 8 & $0.28 \pm 0.03$ & 3.41 & $0.007^{\#}$ \\
VAL & 8 & $0.42 \pm 0.02$ & & \\
C & 8 & $0.28 \pm 0.03$ & 1.16 & 0.274 \\
CRA & 6 & $0.36 \pm 0.06$ & & \\
C & 8 & $0.28 \pm 0.03$ & 1.07 & 0.309 \\
MEL & 6 & $0.33 \pm 0.04$ & \\
\hline
\end{tabular}

$* \mathrm{P}<0.05 ; \# \mathrm{P}<0.01$ 
swim test when Hypericum perforatum extract is applied on rats. ${ }^{11}$ Valepotriates and valerenic acid lead to an increase of Gamma-aminobutyric acid (GABA) in the central nervous system and are responsible for the anxiolytic effect of Valeriana officinalis. ${ }^{12}$ In our experiment, individual extract of this plant reduces significantly the Immobility time in the Forced swim test. Similar results are obtained in a study of Hattesohl et al. ${ }^{13}$ However, in our results the reduction of the immobility time for the combination is higher compared to the reduction caused by both Hypericum perforatum and Valeriana officinalis alone as individual extracts. This implies that a possible synergism of action exists between the three components included in Antistress II. According to the study of Gramowski et al., the antidepressant effect of Hypericum when it is included in combinations with Valeriana and Passiflora is possible with lower doses compared to the mono-preparations of Hypericum. ${ }^{14}$ The other combination - Antistress I did not show antidepressant effect in our experiment. This could be explained by the absence of Hypericum perforatum in the combination and the presences of dry extracts from Melissa officinalis and Crataegus monogyna which are known to possess CNS - depressant effects.

Depressive disorders are often associated with disturbances in the cognition process. ${ }^{15}$ In our experiment we used a novel object recognition test as a simple non-rewarding method to evaluate memory changes in rats. Our results demonstrated that Antistress II facilitates recognition memory in rats subjected to chronic mild stress. All extracts which take part in this combination also improve the cognition significantly when they are administrated separately. Serratula coronata applied as an individual dry extract increases DI value the most compared to the control group. The extract contains 20-hydroxyecdysone which improves the cognition process by exerting antioxidant activity in the brain. ${ }^{16}$ The individual extract of Hypericum perforatum enhances memory by reducing the level of corticosteroids released in the condition of chronic stress therefore diminishing their negative effects on the brain. ${ }^{17}$ Valeriana officinalis also increases the exploration of new objects in the novel object recognition test and the results are similar to those obtained from Nam and coauthors. The mechanism which explains the procognitive effect of the extract is antioxidant activity on the hippocampus and the increase of GABA neurotransmission which promotes dendrite outgrowth of newborn neurons. ${ }^{18} \mathrm{~A}$ slight increase of DI without significance could be observed after the administration of Antistress I on chronically stressed rats. Moreover, the individual extracts of Crataegus monogyna and Melissa officinalis which take part in this combination don't demonstrate statistically significant increase of this indicator, implying a lack of effect on recognition memory.

\section{CONCLUSION}

Antistress II possesses antidepressant effect and improves the recognition memory while Antistress I doesn't demonstrate any of the above-described effects.

\section{ACKNOWLEDGEMENTS}

This present study is funded by the interdisciplinary university project No 10/2015/01.04.2016.

\section{REFERENCES}

1. Matthews K, Robbins TW. Early experience as a determinant of adult behavioural responses to reward: the effects of repeated maternal separation in the rat. 2003;27:45-55.

2. Arbor A. Acute and chronic stress effects on open field activity in the rat: implications for a model of depression. 1981;5:247-51.

3. Kendler KS, Karkowski LM, Prescott CA. Causal relationship between stressful life events and the onset of major depression. Am J Psychiatry 1999;156(6):837-41.

4. Xu P, Wang K, Lu C, et al. Effects of the chronic restraint stress induced depression on reward-related learning in rats. Behav Brain Res 2017;321:185-92.

5. Henningsen K, Andreasen JT, Bouzinova E V, et al. Cognitive deficits in the rat chronic mild stress model for depression: Relation to anhedonic-like responses. Behav Brain Res 2009;198(1):136-41.

6. Sun X, Wang M, Wang Y, et al. Neuroscience Letters Melatonin produces a rapid onset and prolonged efficacy in reducing depression-like behaviors in adult rats exposed to chronic unpredictable mild stress. 2017;642:129-35.

7. Rasoanaivo P, Wright CW, Willcox ML, et al. Whole plant extracts versus single compounds for the treatment of malaria: synergy and positive interactions. Malar J 2011;10(1):S4.

8. Katsarova M, Dimitrova S, Lukanov L, et al. Determination of phenolic acids, flavonoids, terpenes and ecdysteroids in medicinal plant extracts and food supplements. Comptes rendus l'Académie Bulg des Sci. 2017;(in press).

9. Porsolt RD, Le Pichon M, Jalfre M. Depression: a 
new animal model sensitive to antidepressant treatments. Nature 1977;266(5604):730-2.

10. Bevins RA, Besheer J. Object recognition in rats and mice: a one-trial non-matching-to-sample learning task to study "recognition memory". Nat Protoc [Internet]. 2006;1(3):1306-11. Available from: http:// dx.doi.org/10.1038/nprot.2006.205

11. Butterweck V, Wall A, Lieflander-Wulf U, et al. Effects of the total extract and fractions of Hypericum perforatum in animal assays for antidepressant activity. Pharmacopsychiatry 1997;30 Suppl 2:117-24.

12. Yuan C-S, Mehendale S, Xiao Y, et al. The gammaaminobutyric acidergic effects of valerian and valerenic acid on rat brainstem neuronal activity. Anesth Analg 2004;98(2):353-8.

13. Hattesohl M, Feistel B, Sievers H, et al. Extracts of Valeriana officinalis L. s.1. show anxiolytic and antidepressant effects but neither sedative nor myorelaxant properties. Phytomedicine 2008;15(1-2):2-15.

14. Gramowski A, Jügelt K, Stüwe S, et al. Functional screening of traditional antidepressants with primary cortical neuronal networks grown on multielectrode neurochips. Eur J Neurosci 2006;24(2):455-65.

15. Bertaina-Anglade V, Drieu-La-Rochelle C, Mocaër E, et al. Memory facilitating effects of agomelatine in the novel object recognition memory paradigm in the rat. Pharmacol Biochem Behav 2011;98(4):511-7.

16.Xia X, Zhang Q, Liu R, et al. Effects of 20-hydroxyecdysone on improving memory deficits in streptozotocin-induced type 1 diabetes mellitus in rat. Eur J Pharmacol 2014;740:45-52.

17. Trofimiuk E, Walesiuk A, Braszko JJ. St John's wort (Hypericum perforatum) diminishes cognitive impairment caused by the chronic restraint stress in rats. Pharmacol Res 2005;51(3):239-46.

18. Nam SM, Choi JH, Yoo DY, et al. Valeriana officinalis extract and its main component, valerenic acid, ameliorate d-galactose-induced reductions in memory, cell proliferation, and neuroblast differentiation by reducing corticosterone levels and lipid peroxidation. Exp Gerontol 2013;48(11):1369-77. 


\title{
Антидепрессантный эффект и улучшение распознавательной памяти после применения двух нововведённых комбинаций растительно- го экстракта - Антистресс I и Антистресс II у крыс, подвёргнутых воздействию модели хронического лёгкого стресса
}

\author{
Илин К. Кандиларов ${ }^{1}$, Христина И. Златанова ${ }^{1}$, Мария Т. Георгиева-Котетарова ${ }^{1}$, Иван- \\ ка И. Костадинова ${ }^{1}$, Мариана Н. Кацарова², Стела 3. Димитрова", Людмил К. Луканов², \\ Ферит Садаков ${ }^{3}$

\footnotetext{
${ }^{1}$ Кафедра фармакологии и клинической фармакологии, Факультет медицины, Медицинский университет -Пловдив, Пловдив, Болгария

2 Кафедра химии и биохимии, Факультет фармации, Медицинский университет - Пловдив, Пловдив, Болгария

${ }^{3}$ Авицена херб ООО, Пловдив, Болгария
}

Адрес для корреспонденции: Илин К. Кандиларов Кафедра фармакологии и клинической фармакологии, Факультет медицины, Медицинский университет - Пловдив, бул.,Васил Априлов" № 15A, 4002, Пловдив, Болгария

E-mail: ilin.kandilarov@gmail.com Tel: +359892731591

Дата получения: 13 марта 2017 Дата приемки: 24 июня 2017 Дата онлайн публикации: 31 августа 2017

Дата публикации: 30 марта 2018

Ключевые слова: хронический стресс, тест „вынужденного плавания", тест распознавания нового предмета, комбинации растительных экстрактов, Serratula coronate (серпуха венценосная)

\section{Образец цитирования:} Kandilarov IK, Zlatanova HI, Georgieva-Kotetarova MT, Kostadinova II, Katsarova MN, Dimitrova SZ, Lukanov LK, Sadakov F. Antidepressant effect and recognition memory improvement of two novel plant extract combinations - antistress I and antistress II on rats subjected to a model of mild chronic stress. Folia Med (Plovdiv) 2018;60(1):110-6.

doi: 10.1515/folmed-2017-0073
Введение: Хронический стресс является одним из главных факторов, вызывающих депрессию - психиатрическое расстройство, затрагивающее миллионы людей. Предполагается, что оно займёт второе место в ряду причин преждевременной смерти в 2020. Депрессия часто сопровождается когнитивными нарушениями и снижением памяти. Лечение на основе растительных ингредиентов может быть эффективным при терапии депрессии лёгкой и умеренной степени ввиду низкого уровня нежелательных последствий, хорошей переносимости и совместимости.

Материалы и методы: 72 мужские особи крыс линии Вистар, разделенные на 9 групп были подвергнуты пероральному введению в течение 8 недель двух комбинаций экстрактов сухих растений - Антистресс I и Антистресс II и пяти отдельных сухих экстрактов, извлечённых из Serratula coronata, Hypericum perforatum, Valeriana officinalis, Crataegus monogyna и Melissa officinalis. Экспериментальные животные были подвергнуты хроническому непредсказуемому лёгкому стрессу в течение 8 недель. Подобные депрессивным симптомы были оценены при помощи теста „вынужденного плавания“, а оценка снижения памяти осуществилась при помощи теста распознавания нового предмета.

Результаты: Антистресс II показал антидепрессантный эффект в отличие от комбинации Антистресс I, которая не привела к улучшению подобных депрессивным симптомов. Отдельные экстракты Hypericum perforatum и Valeriana officinalis также проявляют антидепрессантные свойства. Антистресс II повышает познавательную способность, также как и отдельные экстракты Hypericum perforatum, Valeriana officnalis и особенно Serratula coronata. Сухой экстракт Serratula по всей вероятности обладает наилучшим эффектом в отношении познавательной памяти. Эффект комбинации Антистресс I в отношении снижения памяти является минимальным.

Заключение: Антистресс II обладает антидепрессантным эффектом и улучшает распознавательную память в отличие от комбинации Антистресс I, которая не проявляет ни одного из вышеупомянутых эффектов. 